\title{
Effect of fat replacement with modified starch on composition and quality of cream cheese
}

\author{
NABIL MEHANNA ${ }^{1}$, ABD EL-AZIZ MAHMOUD ${ }^{1}$, AHMED ELSHENAWY ${ }^{*}$, \\ RASHAD EL-AHWAL ${ }^{2}$
}

${ }^{1}$ Department of Dairy Science, Faculty of Agriculture, Kafrelsheikh University, Egypt

${ }^{2}$ Animal Production Research Institute, Agricultural Research Center, Giza, Egypt

\begin{abstract}
This study aims to produce low-calorie cream cheese (CC) to reduce the problems caused by high-fat cream cheese for some consumers by replacing milk fat with modified starch. Milk fat (MF) of buffalo's milk was partially or fully $(0.0,25,50,75$ and 100\%) replaced by modified starch for making single cream cheese (SCC) or double cream cheese (DCC) aiming to produce low-calorie CC. The cheese samples were analyzed when fresh and after ten days of cold storage. Moisture gradually increased with increasing percentage of replacement and decreased with storage. Replacement of MF decreased protein and increased carbohydrate contents in general, while acidity increased gradually and $\mathrm{pH}$ decreased with increasing percentage of replacement and with storage. Energy content was significantly decreased by more replacement of MF and increased by advancing storage. Spreadability of DCC showed the same trend of energy results. Replacement of MF up to $50 \%$ improved the organoleptic properties while the full replacement adversely affected the organoleptic properties of CC.
\end{abstract}

Keywords Cream cheese, fat replacement, modified starch.

To cite this article: MEHANNA N, EL-AZIZ MAHMOUD AEA, ELSHENAWY A, EL-AHWAL R. Effect of fat replacement with modified starch on composition and quality of cream cheese. Rom Biotechnol Lett. 2021; 26(4): 2793-2799. DOI: $10.25083 / \mathrm{rbl} / 26.4 / 2793-2799$

$\triangle$ *Corresponding author: AHMED ELSHENAWY, Postal address: Dyer Street in Qutour Al Ballad / Qutour Center / Al Gharbia Governorate, Postal code: 31726

E-mail: drahmedelshenawy3@gmail.com Telephone: 00201068082733 


\section{Introduction}

Cream cheese (CC) is a soft un ripened cheese characterized by creamy white colour, smooth texture, good spreadability and pleasant sweet acidic taste since it is acidified by mesophilic lactic acid starter culture (PHADUNGATH [1]; GULZAR \& al [2]; SALARI \& al [3]). As early as 1996, Sanchez \& al [4]. mentioned that $\mathrm{CC}$ is one of the most popular soft cheese in North America and greatly appreciated in UK, Germany and France since such cheese is used as a spread on bread, in sandwiches and as a salad dressing. Such properties are mainly due to fat content. In this respect, $\mathrm{CC}$ products are categorized into two main types based on the fat content in the initial mix and the final composition being SCC with $4.5-5.0 \%$ fat in the initial mix and DCC with at least $9-11 \%$ fat content in the initial mix (GUINEE $\&$ al [5]; PHADUNGATH [1]).

One the other hand, consumption of low-fat dairy products including $\mathrm{CC}$ is quite important since consumers are becoming increasingly aware of the relationship between diet and health and the role of high fat intake on obesity and some diseases (BANKS [6]; AMIRI and NAJAFI [7]; MOHAMED [8]). In this respect, fat may be replaced with lipid -, protein -, or carbohydrate - based ingredients that differ in their functional and sensory properties and their physiological effects (AKOH [9]; MOHAMED [8]). Inulin, maltodextrin and modified starches are examples of fat replacers used in dairy products (ABD EL-KHAIr [10]; ABBAS \& al [11]; FADAEI \& al [12]; ERABY and KOCA, [13]; ALI \& al [14]). In a comprehensive review article, Abbas \& al [11] mentioned that starch is a polysaccharide carbohydrate consisting of a large number of glucose units joined together by glucosidic bodns, whereas modified starches were developed by different means to produce starches suitable for many different functions in food (E1401-E1450) according to the European directive on food additives.

In the present study, milk fat was partially or fully replaced with modified starch aiming to produce a lowcalorie single and double CC.

\section{Materials and Methods}

Fresh buffalo's milk was obtained from Animal Production Research Station in Musa locality, Animal Production Research Institute, whereas modified potato starch (E1422) made in Denmark was purchased from the local importer (Mashreq for business development, Alexandria, Egypt). Starter culture consisting of Lactococcus lactic spp. lactis and Lactococcus lactic spp. cremoris 2794
(1:1) was obtained from Chr. Hansen's Lab., Denmark. MF was partially or fully replaced with modified starch, whereas CC was made according to Guinee \& al [5]. In this respect, buffalo's milk was standardized to contain 5\% and $12 \%$ fat for making single cream cheese (SCC) and double cream cheese (DCC) respectively. Fat was replaced by modified starch at levels of $0.0,25,50,75$ and $100 \%$ before the heat treatment $\left(75^{\circ} \mathrm{C} / 90 \mathrm{sec}\right.$. $)$. The prepared milk was inoculated with mesophilic lactic acid bacteria and incubated at $22-23^{\circ} \mathrm{C}$ for coagulation $(12-16 \mathrm{~h})$ to reach $\mathrm{pH}$ 4.5-4.6. Whey drainage was done in refrigerator using cloth bags. The resultant curd was salted $(1 \%, w / w)$ and stored in plastic cubs at storage temperature of $5 \pm 1^{\circ} \mathrm{C}$.

\section{Analytical methods}

The fresh and stored (10 days in refrigerator) CC samples were analysed for moisture, fat, protein ( $\mathrm{TN}$ x 6.38), acidity and $\mathrm{pH}$ as described by Ling [15]. Carbohydrate was calculated by difference, while the method of IDF [16] was followed for ash determination. Energy was calculated using the equation given by Walstra and Jenness [17], while spreadability was tested as described by Olson and Price [18] as modified by Rayan \& al [19]. The equation used for energy calculation [17] was as follows:

$$
\mathrm{E}=370 \mathrm{~F}+170 \mathrm{P}+168 \mathrm{~L}+18 .
$$

where: $\mathrm{E}=\mathrm{kJ} / \mathrm{kg}, \mathrm{F}=$ Fat content $(\%), \mathrm{P}=$ Protein content $(\%)$ and $\mathrm{L}=$ Lactose or Carbohydrate content $(\%)$. The attained results were expressed as $\mathrm{kJ} / 100 \mathrm{~g}$.

\section{Sensory evaluation}

It was done taking into consideration the devised scoring card mainly and cream cheese samples were organoleptically scored by a regular score panel of some staff members of the dairy departments as recommended by Nelson and Trout [20] and Coutouly \& al [21].

\section{Statistical analysis}

It was carried out using the SPSS 16.0 Syntax Reference Guide (SPSS [22]) Inc. Chicago IL USA. The results were expressed as means with standard errors of the mean. Analysis of variance was carried out, whereas Duncan's test was used to reveal the significant differences between the means as affected by the applied treatments and by the advancing storage time of the prepared product.

\section{Results and Discussion}

Chemical composition of CC was significantly $(\mathrm{P} \leq 0.05)$ affected by replacement of MF with modified starch. This was true with respect to both of fresh and stored SCC (Table 1) and DCC (Table 2). Composition of 
control SCC made with zero replacement (Table 1) was different from the results giver by Elkot and Khalil [23] who gave values $(\%)$ of $68.46,13.5,42.80,16.8$ and 0.92 for moisture, fat, FDM, protein and ash content of fresh SCC respectively, while composition of control DCC (Table 2) was also different from the values given in the literature since the range of moisture was $41.3 \%-58.3 \%$, of fat was $33.1 \%-38.0 \%$ and of protein was $7.0 \%-28.2 \%$ (ABD EL-KHAIR [10]; KWAK \& al [24]; KIM \& al [25]; HAN \& al [26]; JEON \& al [27]; GULZAR \& al [2]). Replacement of MF with modified starch increased moisture and carbohydrate content in general and decreased fat $(\mathrm{P} \leq 0.05)$, FDM $(\mathrm{P} \leq 0.05)$, protein and ash contents of both SCC (Table 1) and DCC (Table 2). Such increase in moisture could be due to ability of starch to catch more moisture, whereas the amount of carbohydrate was proportional with the replacement level by the used polysaccharides. Removing of fat (cream) was responsible for decreasing fat and protein during standardization process. These results are in agreement with those given by Ali \& al [14] and Basiony \& al [28]. The decreased values of ash in treated cheese and the lower values in
DCC are in agreement with Ali \& al [14]) who gave values of $11.73 \%$ and $23.22 \%$ for ash / DM (\%) of full-fat and low-fat $\mathrm{CC}$ respectively. The recorded insignificant decrease in moisture during cold storage of CC may be due to loss some water via evaporation, while such decrease may be responsible for the changes in the other constituents given in Tables (1) and (2). Such changeson storage-agree with the results of $\mathrm{CC}$ given by Perveen \& al [29] and Elkot and Khalil [23]. Perveen \& al [29] mentioned that percent reduction in moisture content of $\mathrm{CC}$ was found to be directly proportional to the increase in storage period. The same authors gave maximum reduction value of $41.03 \%$ when $\mathrm{CC}$ was stored at $21 \pm 1^{\circ} \mathrm{C}$ for 28 days.

Acidity of both SCC (Table 1) and DCC (Table 2) increased gradually with increasing the amount of starch added and during storage. An opposite trend was recorded with $\mathrm{pH}$. Elkot and Khalil [23] gave acidity values (\%) of 0.90 and 0.92 for fresh SCC and DCC respectively, whereas the corresponding values $(\%)$ of stored cheese ( 2 weeks) were 0.94 and 0.97 , whereas those of $\mathrm{pH}$ were $4.6,4.53,4.5$ and 4.43 in order.

Table 1. Chemical composition (\%), acidity (\%) and $\mathrm{pH}$ of fresh and stored single cream cheese (SCC) as affected by replacement of milk fat with modified starch (Average \pm SE of 3 replicates)*

\begin{tabular}{|c|c|c|c|c|c|}
\hline \multirow{2}{*}{$\mathrm{SCC}$} & \multicolumn{5}{|c|}{ Replacement (\%) } \\
\hline & $\mathbf{0 . 0}$ & 25 & 50 & 75 & 100 \\
\hline \multicolumn{6}{|l|}{ Fresh } \\
\hline Moisture & $60.98 \pm 0.18^{\mathrm{cA}}$ & $61.83 \pm 0.73^{\mathrm{cA}}$ & $63.81 \pm 0.35^{\mathrm{bA}}$ & $69.99 \pm 0.61^{\mathrm{aA}}$ & $71.29 \pm 0.34^{\mathrm{aA}}$ \\
\hline Fat & $14 \pm 0.05^{\mathrm{aA}}$ & $11 \pm 0.11^{\mathrm{bA}}$ & $7 \pm 0.05^{\mathrm{cA}}$ & $3.7 \pm 0.11^{\mathrm{dA}}$ & $0.4 \pm 0.03^{\mathrm{eA}}$ \\
\hline Fat / DM & $35.87 \pm 0.31^{\mathrm{aA}}$ & $28.82 \pm 0.25^{\mathrm{bA}}$ & $19.34 \pm 0.34^{\mathrm{cA}}$ & $12.35 \pm 0.63^{\mathrm{dA}}$ & $1.38 \pm 0.08^{\mathrm{eA}}$ \\
\hline Protein & $12.10 \pm 0.20^{\mathrm{aA}}$ & $8.41 \pm 0.09^{\mathrm{bA}}$ & $6.47 \pm 0.10^{\mathrm{cA}}$ & $3.51 \pm 0.11^{\mathrm{dA}}$ & $1.60 \pm 0.10^{\mathrm{eA}}$ \\
\hline Carbohydrate & $10.11 \pm 0.56^{\mathrm{dA}}$ & $16.06 \pm 0.55^{\mathrm{cA}}$ & $20.21 \pm 0.45^{\mathrm{bA}}$ & $20.65 \pm 0.86^{\mathrm{bA}}$ & $24.02 \pm 0.45^{\mathrm{aA}}$ \\
\hline Ash & $2.8 \pm 0.11^{\mathrm{aA}}$ & $2.7 \pm 0.03^{\mathrm{abA}}$ & $2.5 \pm 0.05^{\mathrm{bA}}$ & $2.07 \pm 0.04^{\mathrm{cA}}$ & $2.69 \pm 0.08^{\mathrm{abA}}$ \\
\hline Acidity & $0.8 \pm 0.05^{\mathrm{cA}}$ & $0.9 \pm 0.11^{\mathrm{bcA}}$ & $1.06 \pm 0.03^{\mathrm{abA}}$ & $1.15 \pm 0.08^{\mathrm{aA}}$ & $1.25 \pm 0.05^{\mathrm{aA}}$ \\
\hline $\mathrm{pH}$ & $4.74 \pm 0.08^{\mathrm{aA}}$ & $4.71 \pm 0.06^{\mathrm{aA}}$ & $4.65 \pm 0.09^{\mathrm{aA}}$ & $4.60 \pm 0.05^{\mathrm{aA}}$ & $4.53 \pm 0.07^{\mathrm{aA}}$ \\
\hline \multicolumn{6}{|l|}{ Stored } \\
\hline Moisture & $60.10 \pm 0.51^{\mathrm{dA}}$ & $61.05 \pm 0.40^{\mathrm{dA}}$ & $62.94 \pm 0.39^{\mathrm{cA}}$ & $69.09 \pm 0.61^{\mathrm{bA}}$ & $70.87 \pm 0.40^{\mathrm{aA}}$ \\
\hline Fat & $14.1 \pm 0.11^{\mathrm{aA}}$ & $11.2 \pm 0.05^{\mathrm{bA}}$ & $7.3 \pm 0.17^{\mathrm{cA}}$ & $4 \pm 0.08^{\mathrm{dA}}$ & $0.5 \pm 0.05^{\mathrm{eA}}$ \\
\hline Fat / DM & $35.35 \pm 0.74^{\mathrm{aA}}$ & $28.75 \pm 0.15^{\mathrm{bA}}$ & $19.70 \pm 0.67^{\mathrm{cA}}$ & $12.93 \pm 0.02^{\mathrm{dA}}$ & $1.70 \pm 0.17^{\mathrm{eA}}$ \\
\hline Protein & $11.36 \pm 0.19^{\mathrm{aA}}$ & $8.09 \pm 0.09^{\mathrm{bA}}$ & $6.10 \pm 0.03^{\mathrm{cB}}$ & $3.16 \pm 0.08^{\mathrm{dA}}$ & $1.37 \pm 0.06^{\mathrm{eA}}$ \\
\hline Carbohydrate & $11.53 \pm 0.49^{\mathrm{dA}}$ & $16.86 \pm 0.35^{\mathrm{cA}}$ & $21.06 \pm 0.41^{\mathrm{bA}}$ & $21.57 \pm 0.34^{\mathrm{bA}}$ & $24.44 \pm 0.33^{\mathrm{aA}}$ \\
\hline Ash & $2.9 \pm 0.05^{\mathrm{aA}}$ & $2.8 \pm 0.08^{\mathrm{abA}}$ & $2.6 \pm 0.11^{\mathrm{bA}}$ & $2.17 \pm 0.09^{\mathrm{cA}}$ & $2.810 \pm .46^{\mathrm{abA}}$ \\
\hline Acidity & $1.0 \pm 0.12^{\mathrm{cA}}$ & $1.10 \pm 0.06^{\mathrm{bcA}}$ & $1.20 \pm 0.05^{\mathrm{abcA}}$ & $1.30 \pm 0.02^{\mathrm{abA}}$ & $1.40 \pm 0.08^{\mathrm{aA}}$ \\
\hline $\mathrm{pH}$ & $4.66 \pm 0.12^{\mathrm{aA}}$ & $4.60 \pm 0.09^{\mathrm{abA}}$ & $4.48 \pm 0.08^{\mathrm{abcA}}$ & $4.35 \pm 0.05^{\mathrm{bcB}}$ & $4.29 \pm 0.06^{\mathrm{cA}}$ \\
\hline
\end{tabular}

* Averages with unlike small superscripts (due to treatments) and averages with unlike capital superscripts (due to storage) differed significantly $(\mathrm{P} \leq 0.05)$. 
Table 2. Chemical composition (\%), acidity (\%) and pH of fresh and stored double cream cheese (DCC) as affected by replacement of milk fat with modified starch (Average \pm SE of 3 replicates)*

\begin{tabular}{|c|c|c|c|c|c|}
\hline \multirow{2}{*}{ DCC } & \multicolumn{5}{|c|}{ Replacement (\%) } \\
\hline & 0.0 & 25 & $\mathbf{5 0}$ & 75 & 100 \\
\hline \multicolumn{6}{|l|}{ Fresh } \\
\hline Moisture & $57.82 \pm 1.08^{\mathrm{aA}}$ & $59.10 \pm 0.69^{\mathrm{aA}}$ & $60.57 \pm 1.74^{\mathrm{aA}}$ & $61.30 \pm 0.92^{\mathrm{aA}}$ & $59.50 \pm 0.98^{\mathrm{aA}}$ \\
\hline Fat & $32 \pm 0.28^{\mathrm{aA}}$ & $25 \pm 0.57^{\mathrm{bA}}$ & $17 \pm 0.40^{\mathrm{cA}}$ & $8.2 \pm 0.23^{\mathrm{dA}}$ & $0.4 \pm 0.06^{\mathrm{eA}}$ \\
\hline Fat / DM & $75.99 \pm 2.64^{\mathrm{aA}}$ & $61.20 \pm 2.45^{\mathrm{bA}}$ & $43.37 \pm 2.95^{\mathrm{cA}}$ & $21.17 \pm 0.08^{\mathrm{dA}}$ & $0.99 \pm 0.16^{\mathrm{eA}}$ \\
\hline Protein & $6.48 \pm 0.22^{\mathrm{aA}}$ & $6.21 \pm 0.15^{\mathrm{abA}}$ & $5.78 \pm 0.24^{\mathrm{bA}}$ & $5.06 \pm 0.25^{\mathrm{cA}}$ & $4.32 \pm 0.13^{\mathrm{dA}}$ \\
\hline Carbohydrate & $1.68 \pm 0.75^{\mathrm{eA}}$ & $7.42 \pm 1.06^{\mathrm{dA}}$ & $14.47 \pm 2.30^{\mathrm{cA}}$ & $23.19 \pm 1.02^{\mathrm{bA}}$ & $33.41 \pm 0.97^{\mathrm{aA}}$ \\
\hline Ash & $2.45 \pm 0.06^{\mathrm{aA}}$ & $2.27 \pm 0.05^{\mathrm{abA}}$ & $2.18 \pm 0.09^{\mathrm{bA}}$ & $2.25 \pm 0.07^{\mathrm{abA}}$ & $2.37 \pm 0.06^{\mathrm{abA}}$ \\
\hline Acidity & $0.75 \pm 0.05^{\mathrm{cA}}$ & $0.85 \pm 0.04^{\mathrm{cA}}$ & $1.0 \pm 0.06^{\mathrm{bA}}$ & $1.09 \pm 0.03^{\mathrm{abB}}$ & $1.20 \pm 0.04^{\mathrm{aB}}$ \\
\hline $\mathrm{pH}$ & $4.68 \pm 0.04^{\mathrm{aA}}$ & $4.60 \pm 0.03^{\mathrm{abA}}$ & $4.53 \pm 0.05^{\mathrm{bcA}}$ & $4.45 \pm 0.04^{\mathrm{cA}}$ & $4.39 \pm 0.05^{\mathrm{cA}}$ \\
\hline \multicolumn{6}{|l|}{ Stored } \\
\hline Moisture & $56.48 \pm 0.93^{\mathrm{cA}}$ & $57.28 \pm 0.70^{\mathrm{bcA}}$ & $58.77 \pm 0.71^{\mathrm{abA}}$ & $59.65 \pm 0.37^{\mathrm{aA}}$ & $58.40 \pm 0.46^{\mathrm{abcA}}$ \\
\hline Fat & $32.5 \pm 0.17^{\mathrm{aA}}$ & $26 \pm 0.28^{\mathrm{bA}}$ & $17.5 \pm 0.05^{\mathrm{cA}}$ & $8.5 \pm 0.11^{\mathrm{dA}}$ & $0.5 \pm 0.05^{\mathrm{eA}}$ \\
\hline Fat / DM & $74.75 \pm 1.82^{\mathrm{aA}}$ & $60.86 \pm 0.33^{\mathrm{bA}}$ & $42.47 \pm 0.87^{\mathrm{cA}}$ & $21.07 \pm 0.48^{\mathrm{dA}}$ & $1.19 \pm 0.12^{\mathrm{eA}}$ \\
\hline Protein & $6.30 \pm 0.11^{\mathrm{aA}}$ & $6.09 \pm 0.14^{\mathrm{abA}}$ & $5.59 \pm 0.26^{\mathrm{bA}}$ & $4.91 \pm 0.18^{\mathrm{cA}}$ & $4.22 \pm 0.12^{\mathrm{dA}}$ \\
\hline Carbohydrate & $2.20 \pm 0.95^{\mathrm{aA}}$ & $8.29 \pm 0.21^{\mathrm{dA}}$ & $15.90 \pm 0.46^{\mathrm{cA}}$ & $24.63 \pm 0.63^{\mathrm{bA}}$ & $34.43 \pm 0.34^{\mathrm{aA}}$ \\
\hline Ash & $2.52 \pm 0.04^{\mathrm{aA}}$ & $2.34 \pm 0.06^{\mathrm{bcA}}$ & $2.24 \pm 0.05^{\mathrm{cA}}$ & $2.31 \pm 0.03^{\mathrm{bcA}}$ & $2.45 \pm 0.05^{\mathrm{abA}}$ \\
\hline Acidity & $0.85 \pm 0.07^{\mathrm{dA}}$ & $1.0 \pm 0.06^{\mathrm{cdA}}$ & $1.15 \pm 0.09^{\mathrm{bcA}}$ & $1.30 \pm 0.05^{\mathrm{abA}}$ & $1.40 \pm 0.06^{\mathrm{aA}}$ \\
\hline $\mathrm{pH}$ & $4.62 \pm 0.03^{\mathrm{aA}}$ & $4.54 \pm 0.05^{\mathrm{abA}}$ & $4.46 \pm 0.03^{\mathrm{bA}}$ & $4.39 \pm 0.04^{\mathrm{bcA}}$ & $4.30 \pm 0.06^{\mathrm{cA}}$ \\
\hline
\end{tabular}

* See legend to Table 1 for details.

In a synchronization with fat reduction, the energy significantly decreased to reach minimum values at $100 \%$ replacements. Thus, Table 3 shows that the values were $895.34,821.57,710.31,545.29$ and $447.33 \mathrm{~kJ} / 100 \mathrm{~g}$ of fresh SCC whereas Table 4 reveals corresponding values of $1316.96,1157.02,972.15,780.81$ and $651.32 \mathrm{~kJ} / 100 \mathrm{~g}$ of fresh DCC respectively. Such a significant decrease was also recorded in stored CC shown in Tables 3 and 4. Replacement of more fat with more modified starch was responsible for higher energy values in DCC as compared to those of SCC at any given replacement level.

Spreadability is an important property of CC since-as mentioned elsewhere-CC is used as a spread on bread and sandwiches. Different trend of results was observed between SCC and DCC in this respect. Table 3 shows that the differences in spreadability ( $6 \mathrm{~min}$ ) were insignificant as affected by replacement levels, while the values at $30 \mathrm{~min}$ were almost higher in the treated cheese when compared with the control one (zero replacement). Table 4 reveals that control cheese had significant higher spreadability than the starch treated cheese. This was true in case of fresh and stored DCC, while the stored DCC always had higher spreadability when compared with the fresh one. Gulzar \& al [2] mentioned that when dairy based spreads stored at refrigerating temperature, their spreadability decrease while some other textural defects also arise.

Table 3. Energy (kJ / $100 \mathrm{~g})$, percentage of its decrease and spreadability (mm) of fresh and stored single cream cheese (SCC) as affected by replacement of milk fat with modified starch (Average \pm SE of 3 replicates)*

\begin{tabular}{|c|c|c|c|c|c|}
\hline \multirow{2}{*}{$\mathrm{SCC}$} & \multicolumn{5}{|c|}{ Replacement (\%) } \\
\hline & 0.0 & 25 & 50 & 75 & 100 \\
\hline \multicolumn{6}{|l|}{ Fresh } \\
\hline Energy & $895.34 \pm 3.83^{\mathrm{aB}}$ & $821.57 \pm 15.25^{\mathrm{bA}}$ & $710.31 \pm 3.76^{\mathrm{cB}}$ & $545.29 \pm 8.48^{\mathrm{dA}}$ & $447.33 \pm 8.15^{\mathrm{eA}}$ \\
\hline$\%$ of decrease & 0.0 & $8.23 \pm 2.10^{\mathrm{dA}}$ & $20.66 \pm 0.75^{\mathrm{cA}}$ & $39.10 \pm 1.30^{\mathrm{bA}}$ & $50.03 \pm 0.50^{\mathrm{aA}}$ \\
\hline $\begin{array}{c}\text { Spreadability } \\
6 \text { Min }\end{array}$ & $1 \pm 0.57^{\mathrm{aA}}$ & $1 \pm 0.46^{\mathrm{aB}}$ & $1 \pm 0.57^{\mathrm{aB}}$ & $2 \pm 0.86^{\mathrm{aA}}$ & $1 \pm 0.34^{\mathrm{aB}}$ \\
\hline $30 \mathrm{Min}$ & $7 \pm 0.40^{\mathrm{cB}}$ & $14 \pm 1.15^{\mathrm{aA}}$ & $11 \pm 1.73^{\mathrm{abA}}$ & $9 \pm 0.60^{\mathrm{bcB}}$ & $12 \pm 0.86^{\mathrm{abA}}$ \\
\hline \multicolumn{6}{|l|}{ Stored } \\
\hline Energy & $910.32 \pm 7.27^{\mathrm{aA}}$ & $836.97 \pm 6.48^{\mathrm{bA}}$ & $729.40 \pm 1.16^{\mathrm{cA}}$ & $565.90 \pm 10.49^{\mathrm{dA}}$ & $454.18 \pm 8.73^{\mathrm{eA}}$ \\
\hline $\begin{array}{l}\% \text { of decrease } \\
\text { Spreadability }\end{array}$ & 0.0 & $8.05 \pm 1.45^{\mathrm{dA}}$ & $19.87 \pm 0.77^{\mathrm{cA}}$ & $37.83 \pm 1.65^{\mathrm{bA}}$ & $50.10 \pm 1.46^{\mathrm{aA}}$ \\
\hline 6 Min & $2 \pm 1.15^{\mathrm{aA}}$ & $3 \pm 0.57^{\mathrm{aA}}$ & $5 \pm 0.86^{\mathrm{aA}}$ & $4 \pm 1.10^{\mathrm{aA}}$ & $5 \pm 0.60^{\mathrm{aA}}$ \\
\hline $30 \mathrm{Min}$ & $10 \pm 0.58^{\mathrm{cA}}$ & $13 \pm 1.20^{\mathrm{bA}}$ & $15 \pm 0.60^{\mathrm{abA}}$ & $16 \pm 0.50^{\mathrm{aA}}$ & $6 \pm 1.10^{\mathrm{dB}}$ \\
\hline
\end{tabular}

* See legend to Table 1 for details. 
Table 4. Energy (kJ/100 g), percentage of its decrease and spreadability (mm) of fresh and stored double cream cheese (DCC) as affected by replacement of milk fat with modified starch (Average \pm SE of 3 replicates)*

\begin{tabular}{|c|c|c|c|c|c|}
\hline \multirow{2}{*}{ DCC } & \multicolumn{5}{|c|}{ Replacement (\%) } \\
\hline & 0.0 & 25 & 50 & 75 & 100 \\
\hline \multicolumn{6}{|l|}{ Fresh } \\
\hline Energy & $1316.96 \pm 6.32^{\mathrm{aA}}$ & $1157.02 \pm 0.86^{\mathrm{bB}}$ & $972.15 \pm 19.62^{\mathrm{cA}}$ & $780.81 \pm 21.39^{\mathrm{dA}}$ & $651.32 \pm 16.32^{\mathrm{eA}}$ \\
\hline$\%$ of decrease & 0.0 & $12.14 \pm 0.45^{\mathrm{dA}}$ & $26.18 \pm 1.20^{\mathrm{cA}}$ & $40.71 \pm 1.83^{\mathrm{bA}}$ & $50.54 \pm 1.10^{\mathrm{aA}}$ \\
\hline Spreadability & & & & & \\
\hline 6 Min. & $7 \pm 0.30^{\mathrm{aA}}$ & $3 \pm 0.60^{\mathrm{bA}}$ & $4 \pm 0.50^{\mathrm{bA}}$ & $3 \pm 0.68^{\mathrm{bA}}$ & $1 \pm 0.47^{\mathrm{cA}}$ \\
\hline 30Min. & $18 \pm 0.62^{\mathrm{aA}}$ & $9 \pm 0.40^{\mathrm{bA}}$ & $8 \pm 0.72^{\mathrm{bA}}$ & $6 \pm 0.58^{\mathrm{cA}}$ & $5 \pm 0.67^{\mathrm{cA}}$ \\
\hline \multicolumn{6}{|l|}{ Stored } \\
\hline Energy & $1348.36 \pm 11.55^{\mathrm{aA}}$ & $1206.60 \pm 16.62^{\mathrm{bA}}$ & $1011.45 \pm 10.04^{\mathrm{cA}}$ & $813.55 \pm 3.35^{\mathrm{dA}}$ & $670.46 \pm 9.82^{\mathrm{eA}}$ \\
\hline$\%$ of decrease & 0.0 & $10.51 \pm 0.47^{\mathrm{dB}}$ & $24.98 \pm 0.10^{\mathrm{cA}}$ & $39.66 \pm 0.27^{\mathrm{bA}}$ & $50.27 \pm 0.30^{\mathrm{aA}}$ \\
\hline $\begin{array}{c}\text { Spreadability } \\
6 \text { Min. }\end{array}$ & $8 \pm 0.60^{\mathrm{aA}}$ & $4 \pm 0.44^{\mathrm{bA}}$ & $5 \pm 0.65^{\mathrm{bA}}$ & $4 \pm 0.57^{\mathrm{bA}}$ & $2 \pm 0.32^{\mathrm{cA}}$ \\
\hline 30 Min. & $20 \pm 1.10^{\mathrm{aA}}$ & $10 \pm 0.80^{\mathrm{bA}}$ & $9 \pm 0.66^{\mathrm{bA}}$ & $7 \pm 0.55^{\mathrm{bA}}$ & $8 \pm 1.20^{\mathrm{bA}}$ \\
\hline
\end{tabular}

* See legend to Table 1 for details.

Table 5 shows that the organoleptic properties of both SCC and DCC were greatly affected by the applied treatments whereas the scores given for general appearance, body and texture and flavour of the stored $\mathrm{CC}$ were always less than those given for the fresh CC. However, the scores are given for general appearance and body and texture significantly increased up to $50 \%$ replacement and decreased with more replacement. Partial replacement of MF with modified starch up to $50 \%$ also improved the flavour of $\mathrm{CC}$ while the lowest scores in this respect were given for MF-free CC. This was true in case of both SCC and DCC when fresh or stored suggesting that the optimum percentage of replacement was $50 \%$ only.

Table 5. Scores of the organoleptic properties of fresh and stored (in parenthesis) of both single cream cheese (SCC) and double cream cheese (DCC) as affected by replacement of milk fat with modified starch (Average \pm SE of 10 panelists) ${ }^{*}$

\begin{tabular}{|c|c|c|c|c|c|}
\hline \multirow{2}{*}{ Property } & \multicolumn{5}{|c|}{ Replacement (\%) } \\
\hline & 0.0 & 25 & 50 & 75 & 100 \\
\hline \multicolumn{6}{|l|}{ SCC } \\
\hline $\begin{array}{c}\text { General appearance } \\
(10)\end{array}$ & $\begin{array}{c}8 \pm 0.23^{\mathrm{cA}} \\
\left(7.5 \pm 0.17^{\mathrm{dA}}\right)\end{array}$ & $\begin{array}{c}8.6 \pm 0.20^{\mathrm{bA}} \\
\left(8.25 \pm 0.14^{\mathrm{cA}}\right)\end{array}$ & $\begin{array}{c}9.8 \pm 0.11^{\mathrm{aA}} \\
\left(9.6 \pm 0.17^{\mathrm{aA}}\right)\end{array}$ & $\begin{array}{c}9.5 \pm 0.17^{\mathrm{aA}} \\
\left(9.4 \pm 0.10^{\mathrm{aA}}\right)\end{array}$ & $\begin{array}{l}9.25 \pm 0.15^{\mathrm{aA}} \\
\left(8.8 \pm 0.23^{\mathrm{bA}}\right)\end{array}$ \\
\hline $\begin{array}{l}\text { Body and texture } \\
\qquad(40)\end{array}$ & $\begin{array}{c}34 \pm 0.58^{\mathrm{bA}} \\
\left(33 \pm 0.69^{\mathrm{cA}}\right)\end{array}$ & $\begin{array}{c}35 \pm 0.40^{\mathrm{bA}} \\
\left(34 \pm 0.80^{\mathrm{cA}}\right)\end{array}$ & $\begin{array}{l}39.5 \pm 0.28^{\mathrm{aA}} \\
\left(39 \pm 0.17^{\mathrm{aA}}\right)\end{array}$ & $\begin{array}{c}39 \pm 0.23^{\mathrm{aA}} \\
\left(37.5 \pm 0.52^{\mathrm{abA}}\right)\end{array}$ & $\begin{array}{c}38 \pm 0.86^{\mathrm{aA}} \\
\left(36 \pm 0.58^{\mathrm{bA}}\right)\end{array}$ \\
\hline $\begin{array}{l}\text { Flavour } \\
\qquad(50)\end{array}$ & $\begin{array}{c}46 \pm 0.23^{\mathrm{bcA}} \\
\left(44 \pm 0.18^{\mathrm{bcB}}\right)\end{array}$ & $\begin{array}{c}47 \pm 0.57^{\mathrm{abA}} \\
\left(45 \pm 0.46^{\mathrm{bB}}\right)\end{array}$ & $\begin{array}{l}48.5 \pm 0.87^{\mathrm{aA}} \\
\left(48 \pm 0.58^{\mathrm{aA}}\right)\end{array}$ & $\begin{array}{c}48 \pm 0.30^{\mathrm{aA}} \\
\left(47 \pm 0.63^{\mathrm{aA}}\right)\end{array}$ & $\begin{array}{c}45 \pm 0.35^{\mathrm{cA}} \\
\left(43 \pm 0.75^{\mathrm{cA}}\right)\end{array}$ \\
\hline \multicolumn{6}{|l|}{ DCC } \\
\hline $\begin{array}{c}\text { General appearance } \\
(10)\end{array}$ & $\begin{array}{c}8.5 \pm 0.11^{\mathrm{cA}} \\
\left(8.2 \pm 0.25^{\mathrm{cdA}}\right)\end{array}$ & $\begin{array}{c}9 \pm 0.23^{\mathrm{bA}} \\
\left(8.8 \pm 0.18^{\mathrm{bcA}}\right)\end{array}$ & $\begin{array}{c}9.7 \pm 0.17^{\mathrm{aA}} \\
\left(9.5 \pm 0.28^{\mathrm{aA}}\right)\end{array}$ & $\begin{array}{l}9.3 \pm 0.05^{\mathrm{abA}} \\
\left(9 \pm 0.20^{\mathrm{abA}}\right)\end{array}$ & $\begin{array}{l}8.2 \pm 0.12^{\mathrm{cA}} \\
\left(8 \pm 0.06^{\mathrm{dA}}\right)\end{array}$ \\
\hline $\begin{array}{l}\text { Body and texture } \\
\qquad(40)\end{array}$ & $\begin{array}{c}35 \pm 0.46^{\mathrm{bcA}} \\
\left(34.5 \pm 0.24^{\mathrm{cA}}\right)\end{array}$ & $\begin{array}{c}36 \pm 0.29^{\mathrm{bA}} \\
\left(34 \pm 0.55^{\mathrm{cdB}}\right)\end{array}$ & $\begin{array}{c}39 \pm 0.60^{\mathrm{aA}} \\
\left(38.5 \pm 0.30^{\mathrm{aA}}\right)\end{array}$ & $\begin{array}{c}38 \pm 0.35^{\mathrm{aA}} \\
\left(37 \pm 0.14^{\mathrm{bB}}\right)\end{array}$ & $\begin{array}{c}34 \pm 0.17^{\mathrm{cA}} \\
\left(33 \pm 0.40^{\mathrm{dA}}\right)\end{array}$ \\
\hline $\begin{array}{l}\text { Flavour } \\
\qquad(50)\end{array}$ & $\begin{array}{l}46 \pm 0.57^{\mathrm{bcA}} \\
\left(42 \pm 0.27^{\mathrm{dB}}\right)\end{array}$ & $\begin{array}{l}45 \pm 0.25^{\mathrm{cdA}} \\
\left(43 \pm 0.21^{\mathrm{cB}}\right)\end{array}$ & $\begin{array}{c}48 \pm 0.86^{\mathrm{aA}} \\
\left(46.5 \pm 0.11^{\mathrm{aA}}\right)\end{array}$ & $\begin{array}{l}47 \pm 0.58^{\mathrm{abA}} \\
\left(45 \pm 0.46^{\mathrm{bB}}\right)\end{array}$ & $\begin{array}{c}44 \pm 0.40^{\mathrm{dA}} \\
\left(42 \pm 0.23^{\mathrm{dB}}\right)\end{array}$ \\
\hline
\end{tabular}

\footnotetext{
* See legend to Table 1 for details.
} 
A serious problem in composition and quality of low-fat food products such as CC is mainly due to reduction of fat content since removal of fat from the casein network of cheese results in formation of a much lighter and firmer para-casein network (BANKS [6]; AMIRI and NAJAFI [7]). The recorded changes in the chemical composition of treated $\mathrm{CC}$ could be mainly due to the used modified starch and-in general-the carbohydrate-based fat replacers have the ability to hold more water in cheese matrix and in different food products in general (LUCCA and TEPPER [30]; ALI \& al [14]). However, increasing the moisture content is one of the most important strategies for improving the properties of low-fat cheese (MISTRY [31]). This by its turd decreased values of FDM. Replacement of MF up to $75 \%$ decreased protein content which may be due to loss of some protein during removing of fat, but adding modified starch had an opposite impact on carbohydrate content.

The prementioned changes in acidity may be due to activity of the used starter culture in the presence of more starch, while the changes-on storage-was mainly due to formation of more lactic acid by a predominating lactic acid bacteria. In this respect, Perveen \& al [29] mentioned that conversion of lactose and other sugars to lactic and other acids is responsible for increasing acidity and decreasing $\mathrm{pH}$ during storage of $\mathrm{CC}$.

Energy of any food depends on its fat $(\mathrm{F})$, protein $(\mathrm{P})$ and carbohydrate $(\mathrm{C})$ content but the contribution of both protein and carbohydrate is slightly less or nearly the some of that of fat content.

In fresh SCC, replacement of fat with modified starch increased the percentage of energy decreased from 0.0 to $8.23,20.66,39.10$ and 50.03 when replacement was 25, 50, $75,100 \%$ respectively. The corresponding percentages of decrease in fresh DCC were 12.14, 26.18, 40.71 and 50.54. So, production of low-calorie CC was achieved by partially or totally replace MF with modified starch.

The recorded improvement of most of the organoleptic properties due to the partial replacement of MF with modified starch is mainly due to the functional properties of the used starch in this respect. Lucca and Tepper [30] mentioned that starches of varying sources, types and functional properties are used in fat replacing systems to provide slippery, good mouthfeel and to achieve desired functional and sensory properties. Holding more water is quite important for such improvement, however, it is well-known that starches generally perform well in high moisture foods to enhance the stability, creaminess and different desirable characteristics (LUCCA and TEPPER [30]). In the present study, the prepared SCC and DCC contained moisture more than $50 \%$, which may be responsible for the action of the used modified starch as partial replace of MF in cream cheese.

\section{Conclusion}

It can be concluded from the present study that, lowcalorie cream cheese of good quality can be manufactured from buffalo's milk after partial replacement $(50 \%)$ of its fat by a modified starch. This product can be used to reduce the risk of diseases caused by the consumption of products with high-fat content such as obesity and arteriosclerosis. In addition, this percentage was recommended to reduce the financial cost of the resultant cheese.

\section{Conflict of Interest}

The authors has no conflict of interest to declare.

\section{References}

1. PHADUNGATH, C. Cream cheese products: A review. Songklanakarin. J. Sci. Technol. 2005; 27:191-199.

2. GULZAR N, SAMEEN A, KHAN MI, HUMA N, MURTAZA MA, RAFIQ S. Nutritional and functional properties of fruited cream cheese spread as influenced by hydrocolloids. J. Food Res. Nutr. 2015; 3: 191-195.

3. SALARI S, ZANGANEH M, FADAVI A, AHMED Z. Effect of xanthan gum and carboxymethyl cellulose on chemical and sensory properties of cream cheese. Int. J. Adv. Technol. 2017; 8 :1-6.

4. SANCHEZ C, BEAUREGARD JL, CHASSAGNE MH, BIMBENET JJ, HARDY J. Effects of processing on rheology and structure of double cream cheese. Food Res. Int.,1996; 28: 547-552.

5. GUINEE TP, PUDJA PD, FARKYE NY. Fresh acid curd cheese varieties. 1993; pp. 363-419. In P.F. Fox (ed): Cheese: chemistry, physics and microbiology. vol. 2: Major cheese groups. Chapman \& Hall.

6. BANKS JM. The technology of low-fat cheese manufacture. Int. J. Dairy Technol. 2004; 57: 199-207.

7. AMIRI M, NAJAFI MBH. The effect of adding enzyme-modified cheese on sensory and texture properties of low- and high-fat cream cheese. Int. J. Dairy Technol. 2011; 64: 92-98.

8. MOHAMED AG. Low-fat cheese: A modern demand. Int. J. Dairy Sci. 2015; 10: 249-265.

9. AKOH CC. Fat replacers. Food Technol. 1998; 52: 47-53.

10. ABD EL-KHAIR AA. Rheological and sensory characteristics of half-fat cream cheese made with carbohydrate-based fat replacers. J. Agric. Sci., Mansoura Univ., 2003; 28: 6257-6270.

11. ABBAS KA, KHALIL SK, HUSSIN ASM. Modified starches and their usages in selected food products: A review study. J. Agric. Sci. 2010; 2: 90-100. 
12. FADAEI V, POURSHARIP K, DANESHI M, HONARVAR M. Chemical characteristics of low-fat whey less cream cheese containing inulin as fat replacer. Euro. J. Exp. Bio., 2012; 2: 690-694.

13. ERBAY Z, KOCA N. Effect of whey or maltodextrin addition during production on physical quality of white cheese powder during storage. J. Dairy Sci. 2015; 98: 8391-8404.

14. ALI AA, ABD EL-GHANY IHI, ZEIDAN M, KHEDER AA. Use of hydrocolloids for enhancing Egyptian style low fat white soft cheese attributes. J. Food Dairy Sci., Mansoura Univ., 2016; 7: 363-369.

15. LING ER. A text book of dairy chemistry. Vol. II, Practical., 3rd Ed., Chapman \& Hall, London, UK. 1963.

16. IDF. Determination of the ash content of processed cheese products. Standard No. 27, Int. Dairy Federation, Brussels, Belgium, 1964.

17. WALSTRA P, JENNESS R. Dairy chemistry and physics. $1^{\text {st }}$ Ed., John Wiley \& Sons, 1984.

18. OLSON NF, PRICE WV. A melting test for pasteurized process cheese spread. J. Dairy Sci. 1958; 41: 999-1000.

19. RAYAN AA, KALAB M, ERNSTROM CA. Microstructure and rheology of pasteurized process cheese. 1980; SEM 3: 635-643.

20. NELSON J, TROUT GM. Judging dairy products. 4th Ed., AVI publishing company, INC, Westport, Connecticut, 1981.

21. COUTOUly A, RiAublanC A, AXELOS M, GAUCHER I. Effect of heat treatment, final $\mathrm{pH}$ of acidification, and homogenization pressure on the texture properties of cream cheese. Dairy Sci. Technol. 2013; DOI 10.1007/s13594- 013-0148-z
22. SPSS. SPSS for Windows. Release 13 (Oct., 2007). Standard Version. Copyright SPSS Inc. 2007.

23. ELKOT WF, KHALIL OSF. Impact of type of filling on the quality of cream cheese. J. Food Dairy Sci., Mansoura Univ., 2018; 9: 171-175.

24. KWAK HS, JUNG CS, SHIM SY, AHN J. Removal of cholesterol from Cheddar cheese by B-Cyclodextrin. J. Agric. Food chem. 2002; 50: 7293-7298.

25. KIM SH, HAN EM, AHN J, KWAK HS. Effect of crosslinked B-Cyclodextrin on quality of cholesterolreduced cream cheese. Asian-Aust. J. Anim. Sci. 18: 2005; 584-589.

26. HAN EM, KIM SH, AHN J, KWAK HS. Comparison of cholesterol- reduced cream cheese manufactured using crosslinked B-Cyclodextrin to regular cream cheese. Asian-Aust. J. Anim. Sci. 2008; 21: 131-137.

27. JEON SS, GANESAN P, LEE YS, YOO SH, KWAK HS. Texture and sensory properties of cream cheese and cholesterol-removed cream cheese made from whole milk powder. Korean J. Food Sci. Ani. Resour. 2012; 32: 49-53.

28. BASIONY MMM, EL-NIMER AMM, ELGANDOUR AA. Effect of fat replacers on the quality of low-fat Munster-like cheese. J. Food Dairy Sci., Mansoura Univ., 2017; 8: 93-98.

29. PERVEEN K, ALABDULKARIM B, ARZOO S. Effect of temperature on shelf life, chemical and microbial properties of cream cheese. Afr. J. Biotechnol. 2011; 10: 16929-16936.

30. LUCCA PA, TEPPER BJ. Fat replacers and the functionality of fat in foods: Review. Trends Food Sci. Technol. 1994; 51: 12-19.

31. MISTRY VV. Low fat cheese. Technol. Int. Dairy J. 2001; 11: 413-422. 